\title{
CORRESPONDENCE
}

\section{A USE FOR ACETIC ACID IN THE STUDY OF FOSSIL SPONGES}

SIR,-Most of the macroscopic skeletal remains of sponges which occur in the Upper Cretaceous rocks of Great Britain and Northern Ireland represent members of the classes Demospongia and Hexactinellida, in which the spicules are siliceous. It has long been known (cf. Zittel, 1877) that skeletons of this sort can be extracted from calcareous matrices by use of nitric or hydrochloric acids, provided that they are still in a siliceous condition. Material suitable for treatment in this manner is unfortunately not usual in the British outcrops, being generally restricted to the Schloenbachia varians Zone of southern England and the Inoceramus lingua Zone of Yorkshire. Most other chalk specimens, other than those imbedded in flints, have the skeletal meshwork represented by limonitic material or by hollow moulds in the matrix, or by a combination of both. They are thus generally unsuitable for acid preparation, and have to be extracted mechanically in consequence. There is, however, one type of non-siliceous preservation in which a chemical method can be used. At certain horizons the English and Irish successions contain accumulations of phosphatized sponge remains; that is, of specimens in which the matrix which fills the skeletal meshes is impregnated with phosphatic material. The principal occurrences of specimens of this sort are in the Glauconitic ("Chloritic") Marl of southern England, in the Chalk Rock from Berkshire to Cambridgeshire, and in the Glauconitic ("Chloritic") Chalk of Co. Antrim, Northern Ireland. In the Glauconitic Marl the phosphate is dark brown, dark grey, or black; in the other cases it appears to be of a different type, being typically pink in colour with gradations to yellow or light brown. The skeletal framework is typically represented by hollow moulds, which sometimes contain rod-like internal casts of the axial canals of the spicules. In all the cases cited the sponges are mainly dictyonine Hexactinellida, though lithistid Demospongia may also occur. Specimens of this type are suitable for treatment with acetic acid; because of the differential solubility in this acid of the phosphatized intra-skeletal matrix and the unphosphatized surrounding sediment respectively, it is possible to dissolve away the latter, at a speed suitable for practical use, without affecting the former. As a result, in spite of the absence of actual skeletal meshwork, the specimens can be extracted in the form of sponge pseudomorphs, with matrix cleared from external surfaces, and also from internal circulatory spaces unless it is phosphatized within them.

The details of procedure are as follows. The specimens are placed in a dish or trough, which should be deep enough to allow their complete immersion to at least 1 inch depth. If possible, use an acid-resistant rack, by means of which they can be lifted out. They are then covered with acetic acid in 20 per cent aqueous solution. No advantage seems to be gained by using a weaker solution, but acid of much greater strength may cause crumbling of the phosphatized material. The specimens are removed after three or four hours and examined individually to check suitability for further treatment; poorly phosphatized examples are liable to crumble whatever strength of acid is used, and any showing this tendency extensively should be rejected. Those replaced in the acid should be examined again a day later. After this, they can be left till all unphosphatized material is dissolved. During this stage, additional mechanical preparation may also be helpful. Clearing of sand or glauconite grains from surfaces should be effected with a fine water jet or a soft toothbrush; hard brushing or scraping destroys traces of the skeletal structure. If matrix in internal cavities is also phosphatized, it may be found to become softened by the acid; it can then be worked out at intervals with a knife-blade or needle, care being taken not to touch the sponge surfaces in this process. When extraction is finished, 
specimens need to be cleared of acetate by immersion in water for about a week; running water does not seem necessary provided that changes are made at daily intervals. After this immersion specimens are dried and examined for acetate growths, any showing these requiring further soaking. Once cleared satisfactorily, the material is ready for study or storage. If desired, examples which appear fragile can be strengthened by spraying with dissolved plastic, e.g. Lustrex in benzene.

This technique has been developed mainly for dealing with material from the Chalk Rock and Glauconitic Chalk. It has proved specially valuable in the case of the latter formation, which is often difficult to treat mechanically because of hardness and a considerable content of mineral grains. The same technique is, of course, equally applicable to other phosphatic fossils, such as e.g. the ammonites which occur in this condition in some Cenomanian deposits.

\section{REFERENCE}

Zitrel, K. A. von, 1877. Studien ueber fossile Spongien, Abt. 1, Hexactinellidae. Abh. k. bayer. Akad., Math.-Phys., Cl. xiii, Abt. 1, pp. 1-63, pls. $i$-iv.

R. E. H. REID.

\section{Geology Department, \\ QUEEN'S UNIVERSITY, BELFAST.}

9th December, 1957.

\section{ON SOME TURKISH SEDIMENTS}

SIR, - I recently spent a month in Turkey, and through the kindness of various Turkish geologists was able to see a little of the local geology. Without pretending to be an authority on either country, I would like to draw attention to the remarkable similarity of certain geological features in Turkey to those I described recently in a report of an excursion in Italy (Ager, 1956). Particularly notable is the presence in Turkey of large areas of confused mixed sediments comparable to the Italian Argille scagliose. These Turkish formations have received various names, e.g. the "exotic block series", the "série mixte", the "complexe à facies tectonique brouillé ", and so on ; Blumenthal has called them the "Türlü Güveç" (a Turkish version of Lancashire hot-pot). Exotic blocks found in this mixture include serpentines and pillow-lavas and are recorded as yielding fossils ranging in age from Permian to Cretaceous. Very thick Oligocene and Miocene sedimentation in Turkey is another feature reminiscent of the north Apennine area.

A great deal of work in Turkey has been done by nappe-minded geologists. A non-tectonician may be allowed to wonder if much of the confused geology of Turkey might be explained in terms of tectonic ridges and submarine land-slipping, as in Italy. At Şile on the Black Sea coast, northeast of Istanbul, I saw a fine section of brecciated Upper Cretaceous limestone resting on Eocene nummulitic marls. This has been described by Baykal (1943) as a thrust, with the very coarse breccia as a mylonite. This interpretation has been disputed by other workers, and the section appeared to me to show all the characters of a gravity collapse structure. I made these suggestions to various Turkish geologists and my attention was drawn to a paper by McCallien and Tokay (1951). In this, exotic Carboniferous blocks in the Cretaceous, on the Black Sea coast between Zonguldak and Ereğli, are explained by submarine slumping due to earthquakes. In the discussion of this paper the late Professor C. I. Migliorini commented on the close resemblance of the Turkish photographs to the Argille scagliose of the Apennines.

Another point worth recording is that just west of Sile is a small promon- 